\title{
Molecular characterization of Rhodococcus equi isolates from horses in Poland: $p V a p A$ characteristics and plasmid new variant, 85-kb type V
}

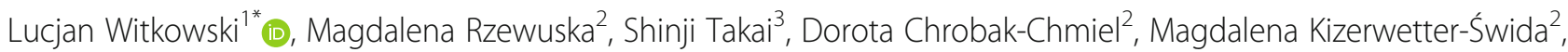
Małgorzata Feret ${ }^{2}$, Marta Gawryś2, Maciej Witkowski ${ }^{4}$ and Jerzy Kita ${ }^{1}$

\begin{abstract}
Background: Rhodococcus equi is one of the most significant bacterial pathogens affecting foals up to 6 months of age worldwide. Rhodococcosis is present in Poland however information about molecular characterization of R. equi isolates is scarce.

This study describes molecular characterization of Rhodococcus equi infection on 13 horse breeding farms in Poland between 2001 and 2012. Samples were collected by tracheobronchial aspiration from pneumonic foals or during necropsy. The $R$. equi isolates were genotyped by plasmid profiling and pulsed-field gel electrophoresis.

Results: Totally, 58 R. equi isolates were investigated. One isolate lost its plasmid. Among the $57 \mathrm{VapA-positive} \mathrm{isolates,}$ 48 contained 85 -kb type I plasmid (82.8\%), 8 contained $87-k b$ type I plasmid (13.8\%). One isolate (1.7\%) had a unique restriction cleavage pattern and the 2 nd fragment of EcoRI digests of this plasmid DNA was about 2600 bases smaller than that of the $85 \mathrm{~kb}$ type I. This new plasmid variant was designated as the "85-kb type V".

Among the 58 isolates typeable with Vspl-PFGE, ten PFGE clusters were detected. The majority of foals were infected mostly with isolates of low genetic diversity.

Conclusions: Most of clinical isolates of R. equi from foals in Poland contain pVapA 85-kb type I and 87-kb type I similarly to the other European countries and the United States. However, the new variant of pVapA 85-kb type V was identified.

The chromosomal variability was detected among some of the investigated isolates and the presence of farm-specific isolates might be possible.
\end{abstract}

Keywords: Rhodococcosis, Epidemiology, PFGE, Horse, Plasmid profile

\section{Background}

Rhodococcus equi is one of the most significant bacterial pathogens affecting foals up to six months of age and occasionally can cause diseases in other animal species including humans [1-6]. Typical manifestation of the infection in foals includes pyogranulomatous bronchopneumonia with abscessation. Epidemiology of the disease is similar worldwide: it occurs endemically on

\footnotetext{
* Correspondence: lucjan_witkowski@sggw.pl

${ }^{1}$ Laboratory of Veterinary Epidemiology and Economics, Faculty of Veterinary Medicine, Warsaw University of Life Sciences, Nowoursynowska 159c, 02-776 Warsaw, Poland

Full list of author information is available at the end of the article
}

some farms and rarely strikes the others. The prevalence and severity of the disease on endemic farms may vary among seasons [1-5]. R. equi infection in foals has been recognized and described in Poland [7-9], but without any information about molecular characterization of $R$. equi isolates. Recently, prevalence of $R$. equi in horse carcasses intended for human consumption was investigated in Poland. Single $R$. equi strain carried 85 -kb type I plasmid was isolated from $0.5 \%(1 / 198)$ samples of healthy middle tracheo-branchiales lymph nodes while no lymphocentrum retropharyngeum sample was positive (0/198) [10]. 
The virulence of $R$. equi is determined by genes vaps located on virulence-associated plasmids (VAPs). Isolates carrying the vapA gene encoding virulence-associated $15-17-\mathrm{kDa}$ protein (VapA) are known as virulent and are capable of causing disease in foals $[11,12]$. To date analysis of the restriction enzyme digestion patterns revealed 12 distinct VAPA types and some of them have geographical specificity [13-24].

Epidemiological studies on genetic relations among $R$. equi isolates are usually based on genotyping by the pulsed-field gel electrophoresis (PFGE) method. Some of the studies report that horses from individual regions or farms seem to harbor isolates with low genetic diversity $[13,23,25]$. On the other side, the great diversity in the genotypes of isolates within and among farms or among countries also has been shown [26]. Furthermore, one foal can be infected with various $R$. equi isolates that vary in plasmid type and genotype [17, 27].

The aim of this study was to characterize types of virulence plasmids in isolates originating from Polish farms and to determine the genetic diversity of the isolates.

\section{Results}

Totally 58 isolates from 13 horse farms were investigated. The isolate ID (code of the horse farm) and year of isolation are presented in Fig. 1. The vapA gene specific for $R$. equi which is virulent for horses was detected in all 58 isolates. However, the virulent VapA-positive isolate 635/05 lost its plasmid during subculturing. Thus, PFGE was performed on 58 whereas plasmid profiling on 57 isolates.

Among 57 VapA-positive isolates, 48 (82.8\%) contained $85-\mathrm{kb}$ type I plasmid, 8 (13.8\%) contained $87-\mathrm{kb}$ type I plasmid (Table 1$)$. One isolate $(1.7 \%$ ) had a unique restriction cleavage pattern and the 2nd fragment of EcoRI digests of this plasmid DNA was about 2600 bases smaller than that of the $85 \mathrm{~kb}$ type I (Fig. 2). This new plasmid variant was designated as the "85-kb type V".

All 58 VapA-positive isolates were typeable with VspIPFGE, resulting in the detection of ten PFGE clusters (from A to J) (Fig. 1). The major cluster (A) was shared by 29 isolates from 8 horse farms. Cluster B was shared by 13 isolates from 3 farms, cluster $C$ by 6 isolates from 2 farms. Four isolates from 2 farms belonged to cluster $\mathrm{D}$ and 2 isolates from one farm belonged to cluster $\mathrm{E}$. The remaining 4 isolates exhibited various pulsed-field patterns. The most of investigated isolates belonged to three main clusters (A. B and C). Part of them were indistinguishable and had the same PFGE pattern despite the fact that they were isolated on various horse farms in various years. PFGE patterns of the isolates were compared with virulence plasmid types and no concordance was observed. Some of the isolates carried pVapA 85-kb type I, 87-kb type I, new variant $85-\mathrm{kb}$ type $\mathrm{V}$, as well as the one had lost the plasmid had the same PFGE pattern.

\section{Discussion}

The prevalence of plasmid 85-kb type I and 87-kb type I in Poland is similar to other studies from Europe [13-15] as well as the USA [16], while in the South America $87-\mathrm{kb}$ type $\mathrm{I}$ is most often isolated than $85-\mathrm{kb}$ type I $[19,28]$. New type of plasmid $85-\mathrm{kb}$ type V might be a local type similar for example to $85-\mathrm{kb}$ type IV in Texas [16] (Table 1).

We were not able to investigate plasmid type in one case because of the plasmid loss [11, 14, 29]. The guidelines for molecular epidemiologic investigation using PFGE assay indicate that the isolate characterization should only be applied to small sets of isolates related to potential outbreaks [30]. In this study, investigated isolates met these criteria as the breeding horse population in Poland is relatively small and mostly concentrated on several breeding farms and most of the isolates used in this study were collected in several years during $R$. equi outbreaks.

The study has several limitations. Firstly, it was a descriptive study: we used the isolates obtained from collaborators as diagnostic material (no random sampling). Secondly, samples were obtained from all of the suspected horses only from a few farms and only during one or a few seasons (farms AA and AB). That's the reason why the isolates from those farms are overrepresented in the analysis. Most of the isolates from the other farms were isolated from individual samples delivered to the laboratory. No data concerning the number of suspected or affected foals on a farm were available. In conclusion, collected isolates and data were not sufficient for the proper statistical analysis and obtained results are only descriptive.

Our results are consistent with some previous data $[13,23,25]$ where a particular isolate or isolates with low genetic diversity are associated with the individual farms or regions. We identified the isolates typical for certain farms. For example almost all predominant isolates from the farm AA belonged to two main PFGE clusters (A and $\mathrm{B}$ ) and most of them were indistinguishable. On the other hand, the same isolates occur on more than one farm, for example on the farms AI and $\mathrm{AL}$ as well as BB and AL. The high similarity of isolates on mentioned farms may be explained by the exchange of mares between them. Mares shed $R$. equi with feces in which the pathogen may multiply and inhalation of virulent $R$. equi is the major route of infection of foals in the first few days of life [3, 5]. Furthermore, the infected foals shed a large amount of VapA positive $R$. equi and this may explain why several major pulsotypes were 


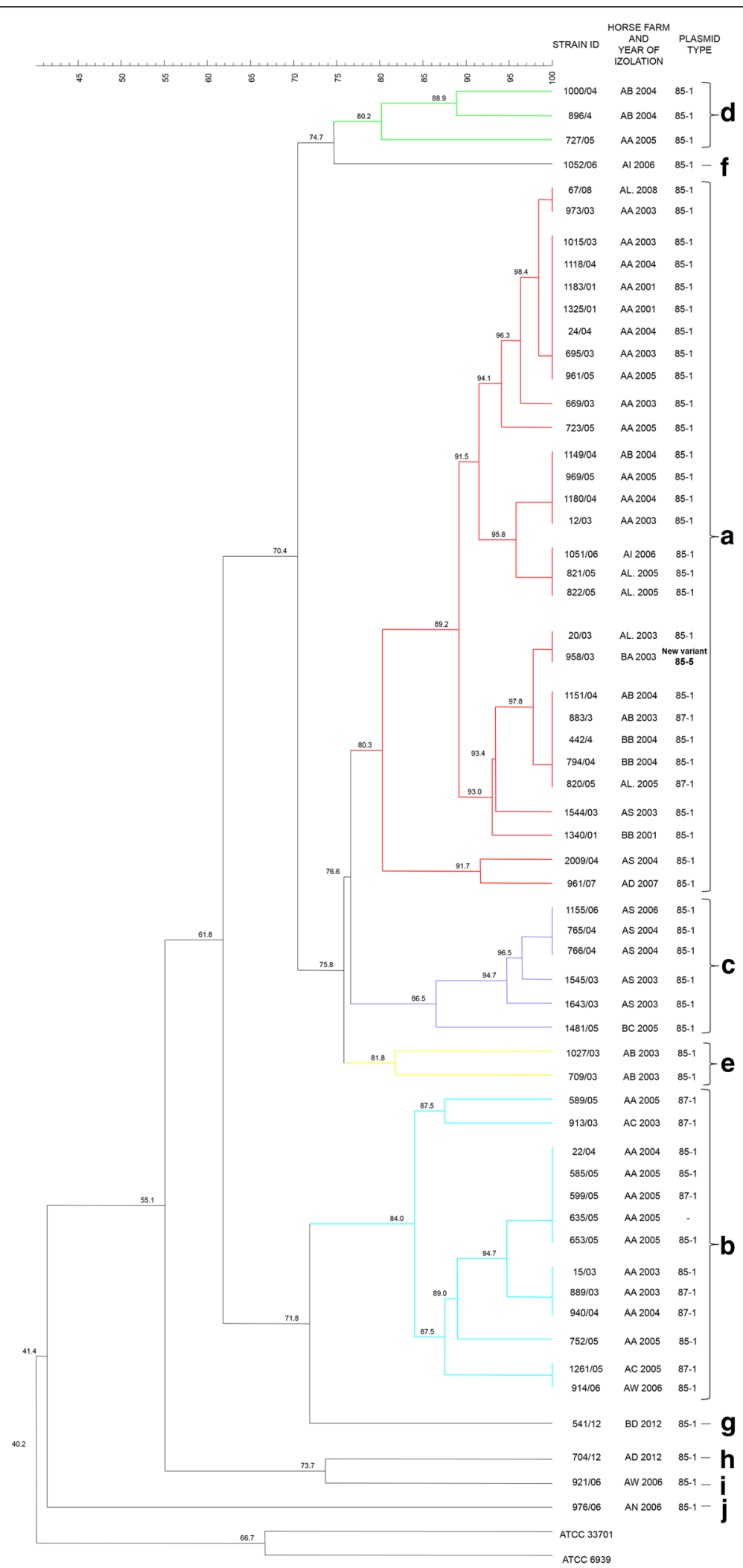

Fig. 1 Dendrogram of 57 virulent and 1 plasmid cured isolates of R. equi obtained from foals from Poland genotyped with Vspl-PFGE method. Among the isolates ten PFGE clusters were detected clusters (a-j) 
Table 1 Plasmid profiles of VapA-positive R. equi

\begin{tabular}{|c|c|c|c|c|c|}
\hline No. & Plasmid type & $\begin{array}{l}\text { Isolation } \\
\text { rate (\%) }\end{array}$ & Sample source & Country & Reference \\
\hline \multirow[t]{15}{*}{1.} & \multirow[t]{15}{*}{ 85-kb type I } & $96.4 \%$ & Foal & Germany & [13] \\
\hline & & $95.3 \%$ & Foal & Hungary & [15] \\
\hline & & $82.8 \%$ & Foal & Poland & This study \\
\hline & & $71.4 \%$ & Soil & Hungary & [20] \\
\hline & & $69.0 \%$ & Foal & France & [14] \\
\hline & & $64.5 \%$ & Soil & USA & {$[16]$} \\
\hline & & $54.2 \%$ & Soil & Hungary & [15] \\
\hline & & $53.1 \%$ & Foal & USA & [16] \\
\hline & & $41.7 \%$ & Soil and feces & France & [14] \\
\hline & & $38.5 \%$ & Foals & Argentina & {$[28]$} \\
\hline & & $14.6 \%$ & Foal & Brazil & [19] \\
\hline & & $14.6 \%$ & Foals & Brazil & [19] \\
\hline & & $3.6 \%$ & Soil & South Africa & [18] \\
\hline & & - & Foals & South Africa & [18] \\
\hline & & $100 \%$ & $\begin{array}{l}\text { Adult horse } \\
\text { lymph node }\end{array}$ & Poland & [10] \\
\hline 2. & 85-kb type II & $4.9 \%$ & Foals & France & [14] \\
\hline \multirow[t]{3}{*}{3.} & \multirow[t]{3}{*}{ 85-kb type III } & $15,3 \%$ & Soil & Hungary & [20] \\
\hline & & $8.0 \%$ & Soil & USA & {$[16]$} \\
\hline & & $4.2 \%$ & Foals & USA & [16] \\
\hline \multirow[t]{2}{*}{4.} & \multirow[t]{2}{*}{ 85-kb type IV } & $2.1 \%$ & Foals & USA & {$[16]$} \\
\hline & & $1.1 \%$ & Soil & USA & {$[16]$} \\
\hline 5. & 85-kb type V & $1.7 \%$ & Foal & Poland & This study \\
\hline \multirow[t]{12}{*}{6.} & \multirow[t]{12}{*}{ 87-kb type I } & $80.5 \%$ & Foals & Brazil & [19] \\
\hline & & $80.0 \%$ & Foals & Brazil & [19] \\
\hline & & $57.7 \%$ & Foals & Argentina & {$[28]$} \\
\hline & & $40.6 \%$ & Foals & USA & [16] \\
\hline & & $27.8 \%$ & Soil and feces & France & [14] \\
\hline & & $26.4 \%$ & Soil & USA & [16] \\
\hline & & $24.6 \%$ & Foals & France & [14] \\
\hline & & $13.8 \%$ & Foal & Poland & This study \\
\hline & & $13.3 \%$ & Soil & Hungary & [15] \\
\hline & & $7.1 \%$ & Soil & South Africa & [18] \\
\hline & & $4.7 \%$ & Foals & Hungary & {$[15]$} \\
\hline & & $3.6 \%$ & Foal & Germany & [13] \\
\hline 7. & 87-kb type II & 85.2 & Foals & Japan & [28] \\
\hline 8. & 87-kb type III & $4.9 \%$ & Foals & Brazil & [19] \\
\hline 9. & 90-kb type I & $74.5 \%$ & Foals and dams & Japan & {$[22]$} \\
\hline \multirow[t]{2}{*}{10.} & 90-kb type II & $47.1 \%$ & $\begin{array}{l}\text { Foals, soil and } \\
\text { feces }\end{array}$ & Korea & [23] \\
\hline & & $0.8 \%$ & Soil and feces & Korea & [24] \\
\hline \multirow[t]{2}{*}{11.} & \multirow[t]{2}{*}{ 90-kb type III } & $24.7 \%$ & $\begin{array}{l}\text { Foals and dams } \\
\text { feces }\end{array}$ & Japan & [22] \\
\hline & & - & Foals & Japan & [14] \\
\hline
\end{tabular}

Table 1 Plasmid profiles of VapA-positive R. equi (Continued)

\begin{tabular}{lllll}
\hline 12. 90-kb type IV & $0.9 \%$ & Foals and dams & Japan & [22] \\
& \multicolumn{2}{l}{ feces } & \\
& - & Foals & Japan & {$[14]$} \\
13. 90-kb type V $52.9 \%$ & $\begin{array}{l}\text { Foals, soil and } \\
\text { feces }\end{array}$ & Korea & {$[23]$} \\
& & Soil and feces & Korea & {$[24]$}
\end{tabular}

widespread in the environment of endemic farms. Moreover, the analyzed samples were collected mostly during outbreaks (rhodococcosis morbidity in foals reached even $100 \%$ ) at relatively close time intervals (year by year).

Comparison of PFGE patterns and plasmid type which was conducted in this study confirms previously indicated observations in horses [13], pigs [31] cattle [32] and wild boars [21]. However, $R$. equi isolates containing the same plasmid type revealed different PFGE patterns and isolates with identical PFGE patterns contained different virulence plasmids or were plasmid-less.

During the study we detected chromosomal variability among some of investigated isolates what had been previously described even among isolates collected from the same farm [26, 33, 34]. However, these studies were

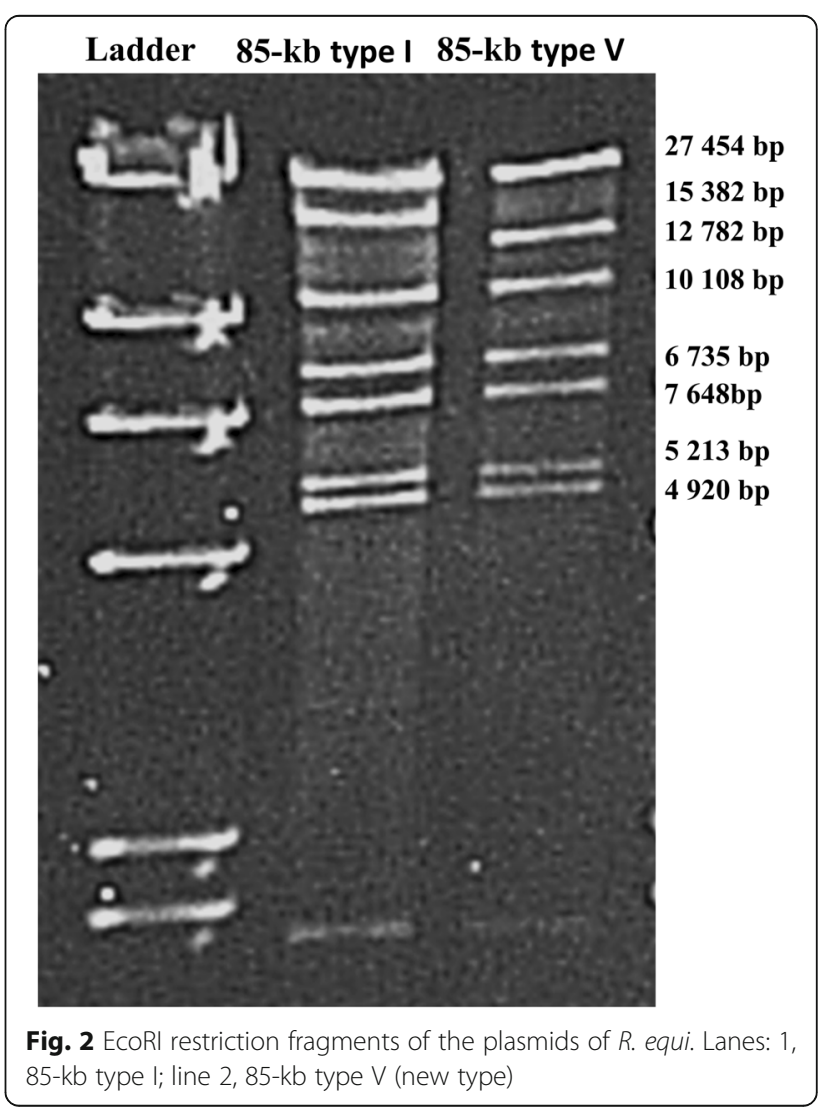


performed on a high number of isolates from heterogeneous horse populations with numerous clinical cases and soil samples from many farms contrary to our study conducted on smaller farms that stay in contact, for example by exchange of the horses.

Given the limitations of this study we can only speculate that the persistence of farm-specific isolates might be possible on some horse farms with limited movement of horses in Poland. Moreover, our observations are supported by reports from Germany and Australia were particular isolates were associated with individual farms $[13,25]$.

\section{Conclusions}

Most clinical isolates of $R$. equi from foals in Poland contain VapA plasmids $85-\mathrm{kb}$ type I and $87-\mathrm{kb}$ type I similar to the other European countries and the United States. There is a new variant of VapA plasmid identified as 85-kb type $\mathrm{V}$.

The chromosomal variability was detected among some investigated isolates, however farm-specific isolates appear to exist.

\section{Methods}

Isolates of $R$. equi were obtained from samples collected by tracheobronchial aspiration from pneumonic foals or during necropsy. Foals originated from 13 horse breeding farms in Poland and were examined between 2001 and 2012.

Bacteria isolation, phenotypic and genotypic identification of isolates were conducted as described previously [35]. Briefly, modified CAZ-NB medium was used for bacteria isolation, API Coryne test (bioMerieux, France) was used for determination of biochemical properties and the presence of "equi factor" was studied in CAMP test. Presence of $R$. equi genes, choE, traA and vapA was determined by PCR. Alkaline lysis method with some modification was used for plasmid DNA isolation from the vapA-positive $R$. equi isolates. Isolated DNA was digested with restriction endonucleases EcoRI, EcoT221, HindIII and BamHI [35-38]. Bacterial DNA extraction and PFGE was performed as previously described [21,23]. The VspI was used as the restriction enzyme. The gel images were analysed by Gel Compar II version 4.6 (Applied Maths, Belgium). Cluster analysis was performed by UPGMA using dice similarity coefficient with optimization set at $1 \%$ and position tolerance at $1.5 \%$. The isolates were considered to be closely related and assigned to the same PFGE cluster using an $80 \%$ of homology cutoff [30]. The reference $R$. equi strains ATCC 6939 and ATCC 33701 were used as controls.

\section{Abbreviations}

PFGE: Pulsed-field gel electrophoresis; VapA: Virulence-associated protein A: VAPS: Virulence-associated plasmids

\section{Acknowledgements}

None.

\section{Funding}

The study was partially supported by a grant from the National Science Centre in years 2010-2013 as a research project No. N N308 131638 and grant from the Polish State Committee for Scientific Research in years 2004-2006 as a research project No. 2 P06K 00627.

Publication was funded by KNOW (Leading National Research Centre) Scientific Consortium "Healthy Animal - Safe Food", decision of Ministry of Science and Higher Education No. 05-1/KNOW2/2015.

\section{Availability of data and material}

The datasets and materials used and/or analysed during the current study available from the corresponding author on reasonable request.

\section{Authors' contributions}

LW acquisition of funding, conceiving, designing and coordination of the study, general supervision of the research group, participation in material and data collection, participation in laboratory analysis, drafting the manuscript. MR participation in acquisition of funding, participation in conceiving and designing the study, participation in laboratory analysis and assistance in drafting the manuscript. ST participation in laboratory analysis and assistance in drafting the manuscript. DCC participation in laboratory analysis and assistance in drafting the manuscript. MKS participation in laboratory analysis and assistance in drafting the manuscript. MF participation in laboratory analysis and assistance in drafting the manuscript. MG participation in laboratory analysis and assistance in drafting the manuscript. MW participation in material and data collection and assistance in drafting the manuscript. JK participation in acquisition of funding, assistance in conceiving and designing the study, assistance in drafting the manuscript. All authors read and approved the final manuscript.

Competing interests

The authors declare that they have no competing interests.

Consent for publication

Not applicable.

Ethic approval and consent to participate

The study was approved by the 3rd Local Commission for Ethics in Animal Experiments (Decision No. 44/2009). Consent was obtained from the owners of the animals used in this study.

\section{Author details}

${ }^{1}$ Laboratory of Veterinary Epidemiology and Economics, Faculty of Veterinary Medicine, Warsaw University of Life Sciences, Nowoursynowska 159c, 02-776 Warsaw, Poland. ${ }^{2}$ Department of Preclinical Sciences, Faculty of Veterinary Medicine, Warsaw University of Life Sciences, Ciszewskiego 8, 02-786 Warsaw, Poland. ${ }^{3}$ Department of Animal Hygiene, School of Veterinary Medicine, Kitasato University, Higashi 23-35-1, Towada, Aomori 034-8628, Japan. ${ }^{4}$ University Center of Veterinary Medicine UJ-UR, Mickiewicza 24/28, 30-059 Cracow, Poland.

Received: 10 October 2015 Accepted: 17 January 2017 Published online: 26 January 2017

\section{References}

1. Chaffin MK, Cohen ND, Martens RJ, Edwards RF, Nevill M. Foal-related risk factors associated with development of Rhodococcus equi pneumonia on farms with endemic infection. J Am Vet Med Assoc. 2003;223(12):1791-9.

2. Muscatello G, Anderson GA, Gilkerson JR, Browning GF. Associations between the ecology of virulent Rhodococcus equi and the epidemiology of R. equi pneumonia on Australian thoroughbred farms. Appl Environ Microbiol. 2006;72(9):6152-60.

3. Giguere S, Cohen ND, Chaffin MK, Hines SA, Hondalus MK, Prescott JF, Slovis NM. Rhodococcus equi: clinical manifestations, virulence, and immunity. J Vet Intern Med. 2011;25(6):1221-30.

4. Muscatello G. Rhodococcus equi pneumonia in the foal-part 1: pathogenesis and epidemiology. Vet J. 2012;192(1):20-6. 
5. Cohen ND. Rhodococcus equi foal pneumonia. Vet Clin North Am Equine Pract. 2014;30(3):609-22.

6. Yamshchikov AV, Schuetz A, Lyon GM. Rhodococcus equi infection. Lancet Infect Dis. 2010;10(5):350-9.

7. Witkowski L, Kaba J, Rzewuska M, Nowicki M, Szalus-Jordanow O, Kita J. Development of ELISA test for determination of the level of antibodies against Rhodococcus equi in equine serum and colostrum. Vet Immunol Immunopathol. 2012;149(3-4):280-5.

8. Gradzki Z, Zietek-Barszcz A. Detection of Rhodococcus equi in tracheobronchial aspirate of foals in enzootic farms depending on age and season. Bull Vet Inst Pulawy. 2011;55(4):619-24.

9. Banbura MW, Witkowski L, Chmielewska A, Tucholska A, Rzewuska M, Ruszczyk A. Isolation of equine herpes viruses type 1 and 2 (EHV-1 and EHV-2) from foals infected with Rhodocaccus equi. Med Weter. 2004;60(12):1333-6.

10. Witkowski L, Rzewuska M, Takai S, Kizerwetter-Swida M, Kita J. Molecular epidemiology of Rhodococcus equi in slaughtered swine, cattle and horses in Poland. BMC Microbiol. 2016;16:98.

11. Vazquez-Boland JA, Giguere S, Hapeshi A, MacArthur I, Anastasi E, Valero-Rello A. Rhodococcus equi: the many facets of a pathogenic actinomycete. Vet Microbiol. 2013;167(1-2):9-33.

12. Ocampo-Sosa AA, Lewis DA, Navas J, Quigley F, Callejo R, Scortti M, Leadon DP, Fogarty U, Vazquez-Boland JA. Molecular epidemiology of Rhodococcus equi based on traA, vapA, and vapB virulence plasmid markers. J Infect Dis. 2007;196(5):763-9.

13. Venner M, Meyer-Hamme B, Verspohl J, Hatori F, Shimizu N, Sasaki Y, Kakuda T, Tsubaki S, Takai S. Genotypic characterization of VapA positive Rhodococcus equi in foals with pulmonary affection and their soil environment on a warmblood horse breeding farm in Germany. Res Vet Sci. 2007:83(3):311-7.

14. Duquesne F, Hebert L, Sevin C, Breuil MF, Tapprest J, Laugier C, Petry S. Analysis of plasmid diversity in 96 Rhodococcus equi strains isolated in Normandy (France) and sequencing of the 87-kb type I virulence plasmid. FEMS Microbiol Lett. 2010;311(1):76-81.

15. Makrai L, Takai S, Tamura M, Tsukamoto A, Sekimoto R, Sasaki Y, Kakuda T, Tsubaki S, Varga J, Fodor L, et al. Characterization of virulence plasmid types in Rhodococcus equi isolates from foals, pigs, humans and soil in Hungary. Vet Microbiol. 2002;88(4):377-84.

16. Takai S, Chaffin MK, Cohen ND, Hara M, Nakamura M, Kakuda T, Sasaki Y, Tsubaki S, Martens RJ. Prevalence of virulent Rhodococcus equi in soil from five $R$. equi-endemic horse-breeding farms and restriction fragment length polymorphisms of virulence plasmids in isolates from soil and infected foals in Texas. J Vet Diagn Invest. 2001;13(6):489-94.

17. Takai S, Murata N, Kudo R, Narematsu N, Kakuda T, Sasaki Y, Tsubaki S. Two new variants of the Rhodococcus equi virulence plasmid, $90 \mathrm{~kb}$ type III and type IV, recovered from a foal in Japan. Vet Microbiol. 2001;82(4):373-81.

18. Takai S, Henton MM, Picard JA, Guthrie AJ, Fukushi H, Sugimoto C. Prevalence of virulent Rhodococcus equi in isolates from soil collected from two horse farms in South Africa and restriction fragment length polymorphisms of virulence plasmids in the isolates from infected foals, a dog and a monkey. Onderstepoort J Vet Res. 2001;68(2):105-10.

19. Ribeiro MG, Seki I, Yasuoka K, Kakuda T, Sasaki Y, Tsubaki S, Takai S. Molecular epidemiology of virulent Rhodococcus equi from foals in Brazil: virulence plasmids of 85-kb type I, 87-kb type I, and a new variant, 87-kb type III. Comp Immunol Microbiol Infect Dis. 2005;28(1):53-61.

20. Makrai L, Kira K, Kono A, Sasaki Y, Kakuda T, Tsubaki S, Fodor L, Varga J, Takai S. Plasmid profiles of virulent Rhodococcus equi isolates from soil environment on horse-breeding farms in Hungary. Acta Vet Hung. 2006;54(1):11-8.

21. Witkowski L, Rzewuska M, Cisek AA, Chrobak-Chmiel D, Kizerwetter-Swida M, Czopowicz M, Welz M, Kita J. Prevalence and genetic diversity of Rhodococcus equi in wild boars (Sus scrofa), roe deer (Capreolus capreolus) and red deer (Cervus elaphus) in Poland. BMC Microbiol. 2015;15(1):110.

22. Yuyama T, Yusa S, Yoshizumi K, Yamano S, Murata S, Hirose T, Osanai R, Onishi Y, Osato S, Sasaki C, et al. Molecular epidemiology of VapA-positive Rhodococcus equi in thoroughbred horses in Kagoshima, Japan. J Vet Med Sci. 2002;64(8):715-8.

23. Son WG, Lee DS, Yamatoda N, Hatori F, Shimizu N, Kakuda T, Sasaki Y, Tsubaki S, Takai S. Molecular typing of VapA-Positive Rhodococcus equi isolates from Jeju native horses, Korea. J Vet Med Sci. 2006;68(3):249-53.

24. Takai S, Son WG, Lee DS, Madarame H, Seki I, Yamatoda N, Kimura A, Kakuda T, Sasaki Y, Tsubaki S, et al. Rhodococcus equi virulence plasmids recovered from horses and their environment in Jeju, Korea: 90-kb type ॥ and a new variant, 90-kb type V. J Vet Med Sci. 2003;65(12):1313-7.

25. Morton AC, Begg AP, Anderson GA, Takai S, Lammler C, Browning GF. Epidemiology of Rhodococcus equi strains on Thoroughbred horse farms. Appl Environ Microbiol. 2001;67(5):2167-75.

26. Cohen ND, Smith KE, Ficht TA, Takai S, Libal MC, West BR, DelRosario LS, Becu T, Leadon DP, Buckley T, et al. Epidemiologic study of results of pulsed-field gel electrophoresis of isolates of Rhodococcus equi obtained from horses and horse farms. Am J Vet Res. 2003;64(2):153-61.

27. Bolton T, Kuskie K, Halbert N, Chaffin K, Healy M, Lawhon S, Jackson A, Cohen N. Detection of strain variation in isolates of Rhodococcus equi from an affected foal using repetitive sequence-based polymerase chain reaction. J Vet Diagn Invest. 2010;22(4):611-5.

28. Takai S, Shoda M, Sasaki Y, Tsubaki S, Fortier G, Pronost S, Rahal K, Becu T, Begg A, Browning $G$, et al. Restriction fragment length polymorphisms of virulence plasmids in Rhodococcus equi. J Clin Microbiol. 1999;37(10):3417-20.

29. Takai S, Ohbushi S, Koike K, Tsubaki S, Oishi H, Kamada M. Prevalence of virulent Rhodococcus equi in isolates from soil and feces of horses from horse-breeding farms with and without endemic infections. J Clin Microbiol. 1991;29(12):2887-9.

30. Tenover FC, Arbeit RD, Goering RV, Mickelsen PA, Murray BE, Persing DH, Swaminathan $\mathrm{B}$. Interpreting chromosomal DNA restriction patterns produced by pulsed-field gel-electrophoresis - criteria for bacterial strain typing. J Clin Microbiol. 1995;33(9):2233-9.

31. Pate M, Ocepek M, Zdovc I, Minato C, Ohtsu Y, Matsuoka M, Honda Y, Hashimoto L, Sasaki Y, Kakuda T, et al. Intermediately virulent Rhodococcus equi isolates from pigs in Slovenia: discovery of new plasmid types and assessment of genetic diversity by pulsed-field gel electrophoresis. Vet Med (Praha). 2009;54(3):111-7.

32. Soedarmanto I, Zhicai W, Setyamahanani A, Lammler C. Pheno- and genotyping of Rhodococcus equi isolated from faeces of healthy horses and cattle. Res Vet Sci. 1998;64(3):181-5.

33. Morton AC, Baseggio N, Peters MA, Browning GF. Diversity of isolates of Rhodococcus equi from Australian thoroughbred horse farms. Antonie Van Leeuwenhoek. 1998;74(1-3):21-5.

34. Martens RJ, Takai S, Cohen ND, Chaffin MK, Liu H, Sakurai K, Sugimoto H, Lingsweiler SW. Association of disease with isolation and virulence of Rhodococcus equi from farm soil and foals with pneumonia. J Am Vet Med Assoc. 2000;217(2):220-5.

35. Rzewuska M, Witkowski L, Cisek AA, Stefanska I, Chrobak D, Stefaniuk E, Kizerwetter-Swida M, Takai S. Characterization of Rhodococcus equi isolates from submaxillary lymph nodes of wild boars (Sus scrofa), red deer (Cervus elaphus) and roe deer (Capreolus capreolus). Vet Microbiol. 2014;172(1-2):272-8.

36. Takai S, Watanabe Y, Ikeda T, Ozawa T, Matsukura S, Tamada Y, Tsubaki S, Sekizaki T. Virulence-associated plasmids in Rhodococcus equi. J Clin Microbiol. 1993;31(7):1726-9.

37. Birnboim HC, Doly J. A rapid alkaline extraction procedure for screening recombinant plasmid DNA. Nucleic Acids Res. 1979;7(6):1513-23.

38. Takai S, Sekizaki T, Ozawa T, Sugawara T, Watanabe Y, Tsubaki S. Association between a large plasmid and 15-kilodalton to 17-kilodalton antigens in virulent Rhodococcus-equi. Infect Immun. 1991;59(11):4056-60.

\section{Submit your next manuscript to BioMed Central and we will help you at every step:}

- We accept pre-submission inquiries

- Our selector tool helps you to find the most relevant journal

- We provide round the clock customer support

- Convenient online submission

- Thorough peer review

- Inclusion in PubMed and all major indexing services

- Maximum visibility for your research

Submit your manuscript at www.biomedcentral.com/submit 